\title{
Thyroid, Parathyroid and Eye Dose Evaluation in Head and Neck Computed Tomography Examinations, Phantom and Clinical Study
}

\author{
A Asgari ${ }^{1,2}$, AA Parach ${ }^{1}$, AA Sharafi ${ }^{3}$, B Nazarparvar ${ }^{4}$, S Parvizi $^{5}$
}

\begin{abstract}
Objectives: Brain computed tomography (CT) scans are approximately $30 \%$ of total computed tomography scan examinations in the world. It is because of the higher sensitivity of the CT for intracephalic organs. Moreover, the probability of abnormalities and cancers in these organs can be increased, therefore, the goal of this study is the measurement of absorbed dose in critical paired organs in brain CT scan, for patient's head surface and for different depths using anthropomorphic phantom and compared with each other.

Methods: In this study, thermoluminescent dosimetries (TLD)-100 were used to measure the absorbed dose of organs in the phantom and 30 patients who underwent brain CT scans. Dosimetry was performed on 30 patients and then the average dose was calculated and compared to phantom data.

Results: Phantom results showed that the average thyroid dose for three different depths were almost the same value and were about $0.6 \mathrm{mGy}$. Dose measurements for parathyroid increased from surface $(2.22$ $m G y)$ to depth $(3.02 \mathrm{mGy})$. Measurements of dose for the front surface of the cornea and eye lens were obtained respectively, $3.73 \pm 0.70 \mathrm{mGy}$ and $3.27 \pm 0.26 \mathrm{mGy}$. The patient's dose measurements also agreed with the phantom surface doses.

Conclusion: It is concluded that the better indication of organ dose is the average dose of each organ from surface to deep, but we can estimate the superficial organ doses from surface dosimetry of each patient and deep organ doses may be estimated accurately using humanoid phantom dosimetry. Also eye lenses receive maximum radiation dose compared to thyroid and parathyroid.
\end{abstract}

Keywords: Computed Tomography (CT), dosimetry, eye, parathyroid, thyroid

\section{Evaluación de las Dosis de Tiroides, Paratiroides y Ojos en los Exámenes de TC, los Estudios de Phantom, y los Estudios Clínicos de Cabeza y Cuello}

\author{
A Asgari ${ }^{1,2}$, AA Parach ${ }^{1}$, AA Sharafi ${ }^{3}$, B Nazarparvar ${ }^{4}$, S Parvizi $^{5}$
}

\begin{abstract}
RESUMEN
Objetivos: La tomografia computarizada (TC) del cerebro representa aproximadamente el $30 \%$ del total de exámenes con escáneres de tomografía axial computarizada en el mundo. Esto se debe a la mayor sensibilidad de la TC frente a los órganos intracefálicos. Por otra parte, puede aumentar la probabilidad de anomalías y cánceres en estos órganos. Por lo tanto, el objetivo de este estudio es la medición de la dosis absorbida en órganos pares críticos en la tomografía del cerebro para la superficie de la cabeza del paciente y para diferentes profundidades utilizando el phantom antropomórfico y comparando las informaciones.

Métodos: En este estudio se usaron dosimetrías termoluminiscentes (TLD)-100 para medir la dosis absorbida de órganos en el phantom y 30 pacientes sometidos a exploraciones de TC del cerebro. La dosimetría se realizó en 30 pacientes y la dosis promedio fue calculada y comparada con los datos del phantom.
\end{abstract}

From: ${ }^{1}$ Department of Medical Physics, Shahid Sadoughi University of Medical Sciences, Yazd, Iran, ${ }^{2}$ Industrial Diseases Research Center, Shahid Sadoughi University of Medical Sciences-Yazd, Iran, ${ }^{3}$ Department of Medical Physics, Iran University of Medical Sciences, Tehran, Iran, ${ }^{4}$ Department of Electrical Engineering, Islamic Azad university East Tehran Branch, Tehran, Iran and ${ }^{5}$ Khatam Al-Anbia University of Applied Science, Tehran, Iran.
Correspondence: Dr AA Parach, Department of Medical Physics, Shahid Sadoughi University of Medical Sciences, Yazd, Iran. E-mail: aliparach@ ssu.ac.ir, aliparach@gmail.com 
Resultados: Los resultados del phantom mostraron que la dosis promedio de tiroides para tres profundidades diferentes tenían casi el mismo valor, que alcanzaba alrededor de $0.6 \mathrm{mGy}$. Las mediciones de dosis de paratiroides aumentaron de superficie $(2.22 \mathrm{mGy})$ a profundidad $(3.02 \mathrm{mGy})$. Las mediciones de dosis para la superficie frontal de la córnea y el cristalino fueron $3.73 \mathrm{mGy} \pm 0,70$ y $3.27 \pm 0.26 \mathrm{mG}$, respectivamente, Las mediciones de dosis del paciente también concordaron con las dosis de superficie de phantom.

Conclusión: Se concluye que la mejor indicación de la dosis del órgano es la dosis promedio de cada órgano de superficie a profundidad, pero podemos estimar las dosis del órgano superficial a partir de la dosimetría superficial de cada paciente, y la dosis de órgano profunda puede estimarse con precisión mediante dosimetría de phantom humanoide. Además, los cristalinos del ojo, recibirán dosis de radiación máxima en comparación con la tiroides y la paratiroides.

Palabras claves: Tomografía computarizada (TC), dosimetría, ojo, paratiroides, tiroides

West Indian Med J 2016; 65 (3): 539

\section{INTRODUCTION}

Ionizing radiation, such as Roentgen radiation, can cause damage to body tissues, especially to the radiosensitive organs (1, 2 ). With the increasing use of various types of computed tomography (CT) scans, concerns about the patients and staff exposure have increased (3). Computed tomography scan requires more patients' exposures than conventional radiography and fluoroscopy. Computed tomography represents $11 \%$ of all diagnostic radiology procedures but it contributes to almost $67 \%$ of the total effective dose to the human population (4). Computed tomography usage has rapidly increased; therefore radiation exposure continues to be the predominant issue in computed tomography (5).

In CT scan of the head and neck region, the patient's head is placed in the radiation field and the exposure of radiation-sensitive organs in the head and neck is imminent. Due to the high sensitivity of some organs such as the eye, thyroid and parathyroid glands, there is an increased risk of cancer in these patients. However, these organs are rarely the main target for imaging $(6,7)$.

It is noted that a 0.5 to 2 Gy radiation $(8-10)$ can cause cataract in adults and even may be less than this amount in children and in some cases the cataract has been reported in about half of this amount. Thus, the estimation of patient dose in head CT scans is of particular importance.

Usually the organ doses in CT examinations is estimated by measuring the surface dose, but for organs located in the depth of the body, measurement of surface dose can cause underestimation. So the main purpose of this study is to measure and estimate the absorbed dose in thyroid, parathyroid glands and the eye lens in the $\mathrm{CT}$ experiments using anthropomorphic phantom at different depths and then at the patient's surface. Finally, the results of patient's data were compared with phantom results.

\section{SUBJECTS AND METHODS}

In this study, parathyroid, thyroid and eye doses in head CT imaging were measured using thermoluminescent dosimetry (TLDs). The measurements were performed using TLDs in anthropomorphic head and neck phantom (11) and then on patients by placing dosimeters on their head and neck during a CT scan. A siemens somatom emotion multislice (6 slices) CT-Scan (Siemens Medical Solutions, Germany) was used in this study.

The phantom constructed from human natural bone as skeletal tissue and paraffin plus $\mathrm{NaCl}$ (for impurity) as softtissue. Phantom dimensions were selected from the standard man. Two important parameters: effective atomic number and electronic density were 6.57 and 3.36 x 1023 electron.gr $^{-1}$, respectively (11).

The TLDs of LiF:Mg,Tl (Harshaw TLD-100) were used for the dose measurement. A Farmer type ionization chamber was used for calibration of the TLDs. This ionization chamber system was calibrated annually by the Iranian Nuclear Agency. For the sensitivity test, TL chips were exposed using an X-ray set with a mean X-ray energy output similar to the output of the CT scanner used. The linearity of TLDs were tested and the results showed a good linear fit with a coefficient of determination $\left(\mathrm{R}^{2}\right)$ of 0.995 . The calculated response of the TLDs was taken as the calibration factor in this study. The results of TLD calibration curve are illustrated in Figure. 1.

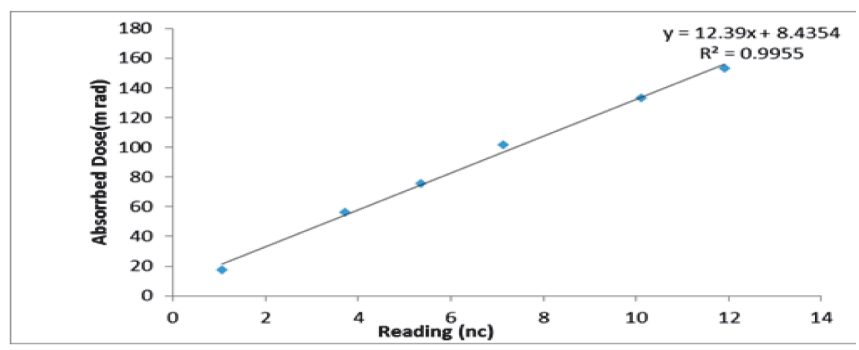

Fig: 1. Calibration curve for thermoluminescent dosimeters.

Thermoluminescent dosimetries then were read with Harshow TLD reader (model 3500). To remove any previously stored energy in the dosimeters, they were heated for one hour at $400{ }^{\circ} \mathrm{C}$ before any exposure. After the TLD reached the am- 
bient temperature, TLDs were heated at $100{ }^{\circ} \mathrm{C}$ for two further hours.

In this step, organ dose measurements were performed on anthropomorphic head and neck phantom (Fig. 2) at different depths using TLDs, as follows:

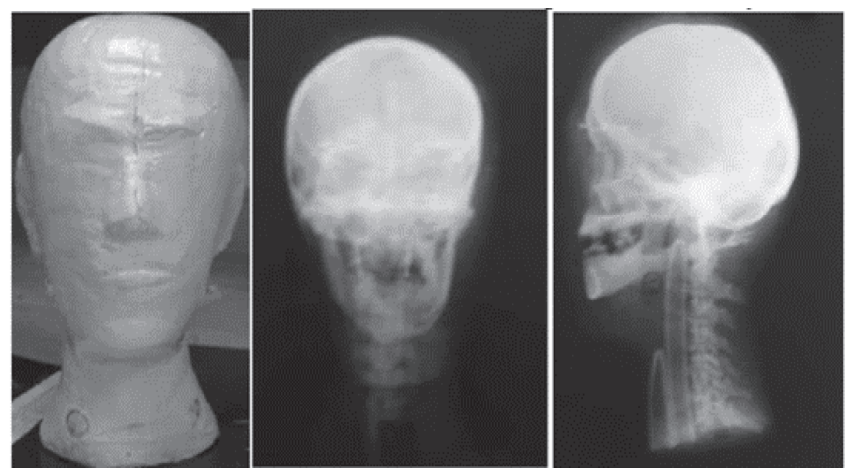

Fig. 2: Head and neck phantom with its antero-posterior and lateral radiographs.

Thyroid and parathyroid doses were measured in three depths: superficial $(0 \mathrm{~cm})$, middle $(1 \mathrm{~cm})$ and deep $(3 \mathrm{~cm})$ in phantom.

The eye dose was measured in two different points: anterior cornea (superficial) and anterior lens (deeper) in anthropomorphic phantom. The exposure parameters used for this study were: $\mathrm{kVp}=130, \mathrm{mAs}=240$, collimation $3 \mathrm{~mm}$, pitch: one with a siemens somatom emotion multislice (6 Slices) CTScan. The TLD readings were carried out after the scanning and calculations of the dose to the organs were done. A minimum of three TLD chips were placed in each measurement point. The exposure was repeated three times (for phantom) to improve the counting statistics.

Finally, dosimetric measurements were performed on patients having head CT scan. For this reason, TLDs were placed on the body surface in thyroids, parathyroids and eyes. In this part, 30 patients with head CT were studied. Thyroid (left and right), parathyroid (left and right) and eyes (left and right) doses for each patient were obtained using three TLDs for each region. All statistical tests were two-sided and $p \leq$ 0.05 was considered statistically significant.

\section{RESULTS}

The patient's data can be seen in Table 1. From this Table, the mean value of the patients' ages (year), heights (m) and weights $(\mathrm{kg})$ were $64 \pm 16,159.2 \pm 12.7,73.5 \pm 7.3$, respectively. The patient's ages, heights and weights ranged from 24-80, 140-180 and 61-90, respectively.

Table 1: Patients characteristics

\begin{tabular}{lcc}
\hline & Mean \pm SD & Range \\
\hline Age (years) & $64 \pm 16$ & $24-80$ \\
Height $(\mathrm{cm})$ & $159.2 \pm 12.7$ & $140-180$ \\
Weight $(\mathrm{kg})$ & $73.5 \pm 7.3$ & $61-90$ \\
\hline $\mathrm{n}=30$ & &
\end{tabular}

Table 2 shows the obtained data at different depths of the thyroid, parathyroid and lens in the phantom and patients. Results showed that the average doses of thyroid from depths of $0,1,3 \mathrm{~cm}$ in phantom were $0.62 \pm 0.13 \mathrm{mGy}, 0.61 \pm 0.09 \mathrm{mGy}$ and $0.59 \pm 0.13 \mathrm{mGy}$, respectively. Dosimetric results for three

Table 2: Results of Phantom and patient dose (mGy) and their relative differences for thyroid, parathyroid and eye lens

\begin{tabular}{|c|c|c|c|c|}
\hline \multirow[t]{2}{*}{ Organ } & \multicolumn{2}{|c|}{ Phantom dose (mGy) } & \multirow{2}{*}{$\begin{array}{c}\begin{array}{c}\text { Patients dose } \\
\text { (mGy) }\end{array} \\
0.62 \pm 0.15\end{array}$} & \multirow{2}{*}{$\begin{array}{c}\begin{array}{c}\text { \% Relative } \\
\text { difference }\end{array} \\
3.2\end{array}$} \\
\hline & 0 (Surface) & $0.60 \pm 0.12$ & & \\
\hline \multirow[t]{3}{*}{ L Thyroid } & 1 (Middle) & $0.60 \pm 0.10$ & - & - \\
\hline & 2 (Deep) & $0.58 \pm 0.13$ & - & - \\
\hline & 0 (Surface) & $0.63 \pm 0.14$ & $0.61 \pm 0.34$ & 3.2 \\
\hline \multirow[t]{3}{*}{ R Thyroid } & 1 (Middle) & $0.61 \pm 0.10$ & - & - \\
\hline & 2 (Deep) & $0.60 \pm 0.14$ & - & - \\
\hline & 0 (Surface) & $2.10 \pm 0.25$ & $2.15 \pm 0.56$ & 2.3 \\
\hline \multirow[t]{3}{*}{ L ParaThyroid } & 1 (Middle) & $2.45 \pm 0.50$ & - & - \\
\hline & 2 (Deep) & $3.03 \pm 0.12$ & - & - \\
\hline & 0 (Surface) & $2.34 \pm 0.22$ & $2.37 \pm 0.65$ & 1.3 \\
\hline \multirow[t]{2}{*}{ R ParaThyroid } & 1 (Middle) & $2.46 \pm 0.24$ & - & - \\
\hline & 2 (Deep) & $3.00 \pm 0.21$ & - & - \\
\hline \multicolumn{5}{|l|}{ Eye not in FOV } \\
\hline \multirow[t]{2}{*}{ L Lens } & Cornea Surface $(0 \mathrm{~mm})$ & $3.13 \pm 0.34$ & $3.04 \pm 0.56$ & 2.9 \\
\hline & Lens Surface (3 mm) & $3.52 \pm 0.70$ & - & - \\
\hline \multirow[t]{2}{*}{ R Lens } & Cornea Surface $(0 \mathrm{~mm})$ & $3.40 \pm 0.17$ & $3.22 \pm 0.52$ & 5.4 \\
\hline & Lens Surface $(3 \mathrm{~mm})$ & $3.93 \pm 0.74$ & - & - \\
\hline \multicolumn{5}{|l|}{ Eye in FOV } \\
\hline \multirow[t]{2}{*}{ L Lens } & Cornea Surface $(0 \mathrm{~mm})$ & $18.53 \pm 2.03$ & - & - \\
\hline & Lens Surface $(3 \mathrm{~mm})$ & $20.95 \pm 4.19$ & $22.08 \pm 2.35$ & 9.2 \\
\hline \multirow[t]{2}{*}{ R Lens } & Cornea Surface $(0 \mathrm{~mm})$ & $18.38 \pm 1.10$ & - & - \\
\hline & Lens Surface $(3 \mathrm{~mm})$ & $20.50 \pm 3.07$ & $22.57 \pm 2.19$ & 9.6 \\
\hline
\end{tabular}


depths of the parathyroid were $2.22 \pm 0.24 \mathrm{mGy}, 2.46 \pm 0.41$ $\mathrm{mGy}$ and $3.02 \pm 0.15 \mathrm{mGy}$, respectively. For the front surface of the cornea and eye lens doses, $3.73 \pm 0.70 \mathrm{mGy}$ and $3.27 \pm$ $0.26 \mathrm{mGy}$ were obtained, respectively. The cornea and lens doses increased to, $18.46 \pm 1.5 \mathrm{mGy}$ and $20.72 \pm 3.2 \mathrm{mGy}$, respectively, when the eye was located in radiation field in the base skull CT scan.

Finally the average dose of thyroids, parathyroids and lenses (not irradiated and irradiated) were: $0.61 \pm 0.12 \mathrm{mGy}$, $2.57 \pm 0.26 \mathrm{mGy}, 3.49 \pm 0.48 \mathrm{mGy}$, and $19.59 \pm 2.6 \mathrm{mGy}$, respectively.

The doses to deeper regions were not measured in patients since the patient dosimetry was performed by placing a dosimeter on the skin surface. Statistical analysis in Table 1 shows a good agreement between the data obtained from the phantom surface and patient skin dose $(p>0.05)$.

It may be said that the depth dose of the phantom can be used as the depth dose indicator of the body because of the agreement between surface dose of phantom and patient. Therefore, the dose of the organ can be obtained with lesser false assumptions and errors by averaging the dose from surface to depth for each organ. As the results showed, the maximum and minimum doses in brain $\mathrm{CT}$ were received by the eye lens and thyroid, respectively.

\section{DISCUSSION}

This study has been done given the importance of dosimetry of critical organs in brain CT imaging and to understand the extent of the damage to these organs. For a better analysis of the results, dosimetries were done on in different depths of the organs of the anthropomorphic head and neck phantom. Surface dose of these organs were measured in patients with brain CT scan.

It is shown that deep organ doses may be estimated using phantom dosimetry due to the similarities of the results of patient skin dose and the phantom surface dose. It can be seen that the thyroid absorbed dose at different depths are nearly identical due to the phantom data. As a result, it can be said that thyroid depth dose may be estimated from thyroid surface dose in brain CT scan while it is not possible to determine the depth dose measurements.

Parathyroid dose - left and right - indicate an increase from the surface to the depth. Statistical analysis also showed no significant differences between left and right organs in patients and phantom measurements. Table 1 shows approximate increase of six times for the eye in CT imaging cut. This issue is crucial especially when the imaging needs to be repeated. As a result, it can be suggested that imaging of the brain is done in such a way that the eye shall not or be less in the CT image cut while maintaining image quality.

This study confirms the results obtained by other researchers as well. Tana et al in 2009, measured the dose received by the lens in the brain imaging for MDCT. They showed that $\mathrm{CT}$ of the temporal bone delivered the greatest radiation dose to the eye lens (12). Hohl and colleagues in 2006 by measuring the skin and organ doses of thyroid and breast showed that the bismuth breast and thyroid shielding significantly decreases radiation dose in MDCT without deteriorating image quality (13).

Lam et al in 2009 also measured the thyroid dose from the CT scan of paranasal sinuses. Their results showed that the thyroid dose was $0.63 \mathrm{mGy}$ which is very closely to our results (14). Jeff et al in 2010 results, about thyroid and lens dose for routine $\mathrm{CT}$ of the brain, stated that lens and thyroid dose ranges were 25.1-50.3 mGy and 0.3-2.8 mGy. Comparison of this range of dose with our data about thyroid and lens showed that the current study results were in the lower extremity of that range and the results are reliable (15).

Table 3 showed the summarized dose for some other studies compare to our study (16-22). None of them measured the parathyroid dose. Most of them reported lens dose and some reported the thyroid dose. Comparison showed that almost all other studies reported higher dose for identical organs than current studied.

It is concluded that deep organ doses may be estimated accurately using humanoid phantom dosimetry but for organs superficially located (such as thyroid) it can be estimated from dosimetry of the surface of the patient. It is also shown that the eye lenses receive maximum dose of radiation compare to thyroid and parathyroid glands in brain CT scans.

Finally, selection of the appropriate exposure conditions, appropriate imaging protocol and proper patient positioning, is necessary to avoid increasing the patient dose so that its sensitive organs are less exposed to radiation while maintaining the image quality.

Table 3: Comparison of organ doses in current and previous studies with computed tomography

\begin{tabular}{|c|c|c|c|c|c|c|c|c|c|c|c|}
\hline Organs & Our study & $\begin{array}{l}\text { Suzuki } e t \\
\text { al (2010) }\end{array}$ & $\begin{array}{l}\text { Bassim et } \\
\text { al (2005) }\end{array}$ & $\begin{array}{c}\text { Shrimpton et } \\
\text { al (1991) }\end{array}$ & $\begin{array}{c}\text { Dose (mGy) } \\
\text { Ngail et al } \\
\quad(2006)\end{array}$ & $\begin{array}{c}\text { Nishizawa et } \\
\text { al (1991) }\end{array}$ & $\begin{array}{c}\text { Tan et al } \\
\text { (2009) }\end{array}$ & $\begin{array}{c}\text { Zammit } \\
\text { (2003) }\end{array}$ & $\begin{array}{l}\text { Lam et al } \\
\quad \text { (2009) }\end{array}$ & $\begin{array}{l}\text { Jeff } e t a l \\
\quad(2010)\end{array}$ & $\begin{array}{l}\text { Abahashemi } \\
\quad \text { (2002) }\end{array}$ \\
\hline Thyroid & 0.6 & $*$ & * & 1.9 & (42 Slice) 2.5 & (9 Slice) 0.6 & $*$ & 2.2 & 1.03 & 2.8 & 2.8 \\
\hline Parathyroid & 2.3 & $*$ & $*$ & $*$ & $*$ & $*$ & $*$ & $*$ & $*$ & $*$ & $*$ \\
\hline Eye lens & 20 & 50 (54 Slice) & 30 & 50 & (42 Slices) 63.9 & (9 Slice) 22.4 & 18 (16 Slices) & 30 & 12.4 (16 Slices) & 34 & * \\
\hline
\end{tabular}

*Data was not recorded 


\section{REFERENCES}

1. Bristow R, Wood R, Clark G. Thyroid dose distribution in dental radiography. Oral Surg Oral med Oral Pathol 1989; 68: 482-7.

2. Ng K, Rassiah P, Wang H, Hambali A, Muthuvellu P, Lee H. Doses to patients in routin X-ray examination in Malaysia. Br J Radiol 1998; 71: 654-60.

3. Blus N, Pages J. Evaluation of patient and staff doses during various CT flouroscopy guided interventions. Health physics 2003; 85: 165-73.

4. Mazonakis M, Tzedakis A, Damilakis J, Gourtsoyiannis N. Thyroid dose from common head and neck CT examinations in children: is there an excess risk for thyroid cancer induction? Eur Radiol 2007; 17: 1352-7.

5. Rogalla P, Stover B, Scheer I, Juran R. Low dose spiral CT in pediatric chest imaging. Pediatr Radiol 1999; 29: 565-9.

6. Rennal M. Caution on Radiation dose. Indian J Radiol Imaging 2000; 10: $19-20$.

7. Haddadi G, Mehdizadeh S, Haddadi M, Meshkibaf M. Evaluation of Absorbed Dose of Critical Organ in Rando Phantom under Head, Abdomen and Pelvis Spiral CT Scan by Thermo Luminescent Dosimetery (TLD). J Fasa Univ Med Sci 2011; 1: 131-5.

8. ICRP. The 2007 Recommendations of the International Commission on Radiological Protection. ICRP Publication 103. Ann ICRP 2007; 37: 54.

9. Shore RE, Neriishi K, Nakashima E. Epidemiological studies of cataract risk at low to moderate radiation doses: (not) seeing is believing Radiat Res 2010; 174: 889-94.

10. Blakely EA, Kleiman NJ, Neriishi K, Chodick G, Chylack LT, Cucinotta FA et al. Radiation cataractogenesis: epidemiology and biology. Radiat Res 2010; 173: 709-17.

11. Hasanzadeh $\mathrm{H}$, Abedelahi $\mathrm{A}$. Introducing a simple tissue equivalent anthropomorphic phantom for radiation dosimetry in diagnostic radiology and radiotherapy. J Paramedical Sci 2011; 2: 25-9.

12. Tana JSP, Tana K-L, Leec JCL, Wana C-M, Leongb J-L, Chan L-L. Comparison of Eye Lens Dose on Neuroimaging Protocols between 16- and
64-Section Multidetector CT: Achieving the Lowest Possible Dose. Am J Neuroradiol 2009; 30: 373-7.

13. Hohl C, Wildberger JE, Suss C, Thomas C, hlenbruch GM, Schmidt T, Honnef D, Günther RW, Mahnken AH. Radiation dose reduction to breast and thyroid during MDCT: effectiveness of an in-plane bismuth shield. Acta Radiologica 2006; 47: 562-7.

14. Lam S, Bux S, Kumar G, Ng K, Hussain A. A comparison between lowdose and standard-dose noncontrasted multidetector CT scanning of the paranasal sinuses. Biomed Imaging Interv J 2009; 5: 1-12.

15. Jaffe TA, Hoang JK, Yoshizumi TT, Toncheva G, Lowry C, Ravin C. Radiation dose for routine clinical adult brain CT: Variability on different scanners at one institution. Am J Roentgenol 2010; 195: 433-8.

16. Lam S, Bux S, Kumar G, Ng K, Hussain A. A comparison between lowdose and standard-dose noncontrasted multidetector CT scanning of the paranasal sinuses. Biomed Imaging and Interv J 2009; 5: e13.

17. Tan J, Tan K, Lee J, Wan C, Leong J, Chan L. Comparison of eye lens dose on neuroimaging protocols between 16- and 64-section multidetector CT: Achieving the lowest possible dose. Am J Neuroradiol 2009; 30: $373-7$.

18. Ngaile JE, Msaki PK. Estimation of patient organ doses from CT examinations in Tanzania. J Appl Clin Med Phys 2006; 7: 80-94.

19. Suzuki S, Furui S, Ishitake T, Abe T, Machida H, Takei R. Lens exposure during brain scans using multidetector Row CT scanners: Methods for estimation of lens dose. Am J Neuroradiol 2010; 31: 822-6.

20. Abahashemi F, Bahraynee M, Sharafi A, editors. Measurment of thyroid dose due to scatter radiation during thoracic imaging. The $5^{\text {th }}$ Iranian medical physics congress; 2002; Tehran: Iran.

21. Jaffe TA, Hoang JK, Yoshizumi TT, Toncheva G, Lowry C, Ravin C. Radiation dose for routine clinical adult brain CT: Variability on different scanners at one institution. Am J Radiol 2010; 195: 433-8.

22. Bassim MK, Ebert CS, MPH RCS, Brent A. Senior. Radiation dose to the eyes and parotids during $\mathrm{CT}$ of the sinuses. Otolaryngol Head Neck Surg 2005; 133: 531-3. 